\title{
PEMBELAJARAN KOSAKATA BAHASA ASING PADA ANAK TK DENGAN METODEDRILLING
}

\author{
Neni Suryanirmala, Akmaluddin, Rabiatul Adawiyah \\ Amikom Mataram, UIN Mataram, Guru TKIT Anak Sholeh Kediri \\ akmal@uinmataram.ac.id. akmalwiya@@gmail.com
}

\begin{abstract}
Abstrak: Pemebelajaran bahasa bahasa asing pada berbagai jenjang pendidikan cenderung lebih menekankan siswa mengerti tentang bahasa, bukan agar siswa mampu menggunakan bahasa yang dipelajari. Untuk meminimalisasi kebiasaan ini, metode pengajaran bahasa asing harus ditata ulang.Berdasarkan hal tersebut, penelitian ini hadir dengan tujuan untuk menjelaskan metode pengajaran bahasa asing yang cukup efektif yaitu metode drilling. Sebagai sebuah metode, drillingtepat digunakan untuk melatih siswa menghafal kosakata baru. Data dalam penelitian ini berupa kosakata bahasa asing yang diajarkan pada anak TK. Adapun teknik pengumpulan data yang digunakan adalah metode observasi yaitu mengamati proses pembelajaran bahasa asing (bahasa Arab dan Inggris) yang diverbalisasikan secara kontinyu oleh guru dan siswa. Adapun teknik analisis data yang digunakan dalam penelitian ini adalah analisis kualitatif komparatif. Artinya semua data yang terkumpul dianalisis dan dibandingkan. Berdasarkan analisis tersebut dapat dilihat kelas kata yang paling dominan dikuasai siswa.

Hasil penelitian ini menunjukkan bahwa kelas kata yang paling dominan dikuasai siswa TKIT Anak Sholeh Kediri adalah kelas kata kerja dengan tingkat persentase penguasaan mencapai $88 \%$, setelah itu kata benda dengan persentase penguasaan mencapai $87 \%$, kemudian disusul kata sifat dengan pesentase penguasaan mencapai $83 \%$ dan terakhir kata bilangan dengan persentase penguasaan mencapai $73 \%$.
\end{abstract}

Kata kunci : kosakata, bahasa asing, metode drilling

\section{A. PENDAHULUAN}

Penguasaan bahasa asing lebih dari satu (dwibahasawan) merupakan hal yang sangat diperlukan pada era globalisasi. Dewasa ini bahasa asing terutama bahasa Inggris menjadi bahasa pengantar dan bahasa pengembang ilmu pengetahuan.Untuk dapat menggali informasi dari sumber-sumber ilmu pengetahuan tersebut harus dipahami bahasa yang digunakan sebagai pengantarnya. Hal ini menyaratkan bahwa penguasaan bahasa asing harus dipenuhi oleh setiap orang yang ingin menguasai ilmu pengetahuan tersebut. Atas dasar inilah penguasaan bahasa asing sejak dini harus diupayakan. 
Terdapat suatu kesenjangan antara harapan dan kenyataan dijumpai saat ini tentang pembelajaran bahasa asing melalui lembaga formal. Pada satu sisi, pembelajaran bahasa asing di sekolah-sekolah yang ada diIndonesia sangat ditunjang oleh fasilitas belajar yang cukup lengkap, namun hasilnya tidak sampai pada kondisi yang menggembirakan. Hal ini ditandai dengan kurangnya kemampuan siswa-siswa dalam penggunaannya.

Realita kurangnya kemampuan siswa dalam penggunaan bahasa kedua (bahasaasing) ini diperkuat oleh simpulan hasil penelitian Kelly pembelajaran bahasa kedua yang menyatakan bahwa meskipun studi tentang metodologi belajar bahasa kedua (bahasa asing) telah sedemikian lama dan dengan biaya yang cukup besar, namun belum banyak mengubah cara orang belajar bahasa, dengan demikian hasilnya pun tidak kunjung maksimal. Sebagai bahan hipotesis diasumsikan bahwa metode pengajaran bahasa asinglah yang perlu mendapat perhatian serius sehingga perlu penataan. Pengajaran bahasa kedua dengan tipe formal perlu ditinjau kembali sehingga realita yang dijumpai saat ini dapat diminimalisasi.

Penggunaan metode drilling diharapkan memudahkan siswa pada tingkat TK dalam menguasai bahasa asing. Penggunaan metode ini sebagai solusi terhadap kesenjangan antara harapan dan kenyataan. Penerapanmetode drilling ini dilakukan di Taman Kanak-Kanak Anak Sholeh Kediri sebagai sampel penelitian yang akan dilakukan. Metode ini akanditerapkan pada TK Anak Sholeh Kediri yang dalam proses belajarnya mengajarkan bahasa asing pada siswanya.

Adapun penerapan metode drilling difokuskan pada penguasaan kosakata bahasa asing pada anak TK. Kosakata tersebut adalah berupa nomina (kata benda), adverbia (keterangan), ajektiva (kata sifat) dan numeralia (katabilangan). Pengajaran kosakata bahasa asing pada anak TK penting untuk mengenalkan tentang referen yang dikandung oleh kosakata tersebut. Selain itu pengajaran kosakata bahasa asing penting agar anak yang masuk sekolah dasar tidak ketinggalan dalam pemberian makna terhadap kosakata bahasa asing yang ditemukan di sekolah dasar. Atas dasar inilah penelitian ini dilakukan pada anak TK dengan fokus kajian peningkatan penguasaan kosakata bahasa asing.

\section{B. KAJIAN PUSTAKA}

\section{Penguasaan}

Penguasaan adalah proses, cara, perbuatan menguasai atau menguasakan, pemahaman untuk kesanggupan untuk menggunakan pengetahuan,kepandaian dan sebagainya (Kamus Besar Bahasa Indonesia, 2008:692).Penguasaan dalam penelitian ini adalah bagaimana tingkat penguasaan siswa TKIT Anak Sholeh Kediri 
dalam pembelajaran kosakata bahasa asing dengan menggunakan metode drilling. Penguasaan ini ditunjukkan oleh persentase hasil pengujian.

\section{Kosakata}

Kosakata adalah himpunan kata yang diketahui oleh seseorang atau entitas lain, atau merupakan bagian dari suatu bahasa tertentu (Kamus Besar Bahasa Indonesia,2008: 692). Kosakata yang dimaksudkan dalam penelitian ini adalah kosakata bahasa asing yaitu bahasa Arab dan bahasa Inggris yang diajarkan pada anak TKIT Anak Soleh Kediri.Adapun kelas kata bahasa asing yang diajarkan adalah kelas kata benda, kata kerja, kata sifat, dan kata bilangan.

\section{Bahasa asing.}

Bahasa asing adalah bahasa milik bangsa lain yang dikuasai biasanya melalui pendidikan formal dan secara sosiokultural tidak dianggap sebagai bahasa sendiri (Kamus Besar Bahasa Indonesia 2008:20). Dalam penelitian ini, bahasa asing yang dimaksud adalah bahasa Arab dan bahasa Inggris.

\section{Metode}

Metode adalah cara teratur yang digunakan untuk melaksanakan suatu pekerjaan agar tercapai sesuai dengan yang dikehendaki;cara kerja yang bersistem untuk memudahkan pelaksanaansuatu kegiatan guna mencapai tujuan yang ditentukan (Kamus Besar Bahasa Indonesia,2008:114). Dalam penelitian ini, metode yang dimaksud adalah metode drilling verbalisasai atau pembiasaan yang diverbalkan dengan frekuensi pengulangan sebanyak 16 kali.

\section{Drilling}

Drilling adalah latihan yang diulang-ulang dalam waktu singkat (Kamus Besar bahasa Indonesia 2008: 264). Dalam penelitian ini, drilling dilakukan dalam waktu 30 menit.

\section{Verbalisasi}

Verbalisasi adalah penjelasan sesuatu dengan kata-kata;pengubahan kata atau frasemenjadi verba dengan derivasi yang sesuai;pengungkapan suatu bahasa (Kamus Besar Bahasa Indonesia, 2008: 856). Verbalisasi dalam penelitian ini adalah mengucapkan kata-kata yang diajarkan secara lantang untuk menambah daya ingat siswa. 


\section{METODE PENELITIAN}

\section{Pendekatan dan Sifat}

Pendekatan yang digunakan dalam penelitian ini adalah kualitatif dan kuantitatif. Hal ini disebabkan karena data yang diperoleh, dianalisis dan disajikan tidak hanya dalam bentuk deskripsi kualitatif atau berupa kata-kata tetapi jugPenelitian ini dimaksudkan untuk mengetahui penerapan metode drilling sebagai upaya untuk meningkatkan penguasaan kosakata bahasa asing pada anak usia dini. Hasil dari penerapan metode ini selanjutnya akan diinterpretasikan menggunakan kata-kata untuk mengukur perubahaan pengetahuan yang terjadi pada siswa usia dini tersebut. Perubahan tersebut adalah dari tidak tahu menjadi tahu, bahkan menguasai kosakata bahasa asing yang diajarkan oleh guru. Dengan demikian, pendekatan kualitatif ini dibutuhkan untuk kepentingan penganalisisan hasil pembelajaran, serta pada akhirnya digunakan juga untuk menyajikan hasil penelitian angka-angka..

\section{Subjek Penelitian}

Penelitianini dilakukan di TKIT Anak Sholeh Kediri pada saat siswa TK tersebut diajarkan kosakata bahasa asing. Siswa TKIT Anak Sholeh Kediri yang dijadikan sebagai subjek penelitian ini berasal dari latar belakang keluarga yang berbeda-beda.

\section{Metode dan Teknik Pengumpulan data}

Metode yang digunakan dalam mengumpulkan data dalam penelitian ini adalah observasi atau pengamatan. Observasi dilakukan dengan mengamati proses pembelajaran bahasa asing yaitu bahasa Arab dan Inggris yang diverbalisasikan secara kontinual oleh guru dan siswa. Selanjutnya metode simak digunakan untuk menyimak frekuensi verbalisasi setiap kata bahasa asing yang diajarkan di dalam kelas untuk mengetahui tingkat penguasaan para siswa. Metode berikutnya adalah wawancara, digunakan untuk mengumpulkan data yang relevan mengenai peserta didik dalam hal pencapaian tingkat penguasaan yang optimal. Wawancara dilakukan dengan guru kelas B1 sebagai subjek dalam penelitian ini.

\section{Penganalisisan Data}

Data yang telah terkumpul selanjutnya dianalisis. Langkah pertama dalam penganalisisan data yaitu dengan mengklasifikasikan kata-kata berdasarkan kelas kata masing-masing yaitu kelas kata benda, kata kerja, kata sifat, dan kata bilangan. Tahapan selanjutnya adalah tabulasi klasifikasi kelas kata untuk melihat persentase penguasaan siswa terhadap setiap kelas kata yang diajarkan. Persentase penguasaan siswa ini dilihat berdasarkan perhitungan rumus:

$$
\% \text { Penguasaan }=\frac{\text { persentase penguasaan kata yang diajarkan }}{\text { jumlah kata yang diajarkan }}
$$


Berdasarkan tabulasi tersebut dapat dilihat kelas kata apa yang paling dominan dikuasai siswa.Dengan demikian, kemampuan siswa dalam menguasai kosakata bahasa asing yang diajarkan dengan metode drilling dapat dilihat berdasarkan persentase kelas kata yang diperoleh.

\section{Pembahasan}

\section{Deskripsi Kelas Kata yang Diajarkan}

Data dalam penelitian ini berupa data verbal yaitu jenis atau kelas kata bahasa asing yang diajarkan pada mata pelajaran muatan lokal pada jenjang sekolah TK. Dalam hal ini, sekolah TK yang menjadi tempat penelitian adalah TKIT Anak Sholeh Kediri, Lombok Barat. Kosakata bahasa asing diajarkan di TKIT Anak Sholeh Kediri sebagai bahan pelajaran muatan lokal. Pengajaran kosakata bahasa asingini ditekankan pada dua kosakata bahasa asing yaitu bahasa Inggris dan bahasa Arab. Pengajaran kosakata bahasa Inggris dilakukan sebagai bentuk kesadaran akan posisi bahasa Inggris sebagai bahasa dunia yang perlu dikuasai. Sedangkan pengajaran kosakata bahasa Arab dilakukan karena bahasa Arab diidentikkan dengan Islam yang menjadi dasar TKIT Anak Sholeh Kediri. Dengan demikian pengajaran kedua kosakata bahasa asing ini sebagai bentuk penyeimbang antara dua sisi yaitu pengetahuan global yang diwakili bahasa Inggris dan pengetahuan keislaman yang diwakili bahasa Arab. Di samping itu pengajaran kosakata kedua bahasa asing tersebut merupakan bentuk keterpaduan yang menjadi ciri khas sekolah tersebut.

Pengajaran kosakata kedua bahasa asing tersebut di atas tentunya tidak sekompleks pengajaran pada sekolah lanjutan. Hal ini disesuaikan dengan tingkat berfikir peserta didik yang masih sederhana. Sebagaimana yang telah dijelaskan pada bab sebelumnya bahwa terdapat berbagai macam kelas kata yang dimiliki satu bahasa. Atas keragaman tersebut dilakukan pemilahan terhadap kelas kata yang sesuai dengan tingkat berfikir peserta didik. Pemilahan kelas kata yang diajarkan ini berpegang pada konsep bahasa anak TK yaitu kini dan sini. Beberapa kelas kata yang dapat dijadikan sebagai representasi konsep kini dan sini tersebut adalah kelas kata benda, kelas kata kerja, kelas kata sifat dan, kelas kata bilangan.

Keempat kelas kata tersebut merupakan kelas kata yang paling banyak diajarkan pada jenjang sekolah TK. Berdasarkan hasil penelitian yang telah dilakukan di sekolah TKIT Anak Sholeh Kediri, di bawah ini akan diuraikan gambaran kelas kata serta contoh masing-masing kelas kata yang diajarkan pada jenjang sekolah tersebut.

a. Kata benda

Adapun jenis kata benda yang diajarkan pada anak TKIT Anak Sholeh Kediri dapat dilihat pada tabel berikut. 
Tabel 3.

Daftar Kata Benda yang Diajarkan pada Anak TKIT Anak Sholeh Kediri

\begin{tabular}{|c|c|c|c|}
\hline No & Kata Benda & Bahasa Inggris & Bahasa Arab \\
\hline A. & \multicolumn{3}{|c|}{ Anggota Keluarga } \\
\hline 1 & bapak & father & آَبْ \\
\hline 2 & $i b u$ & mother & امَ \\
\hline 3 & saudara laki-laki & brother & 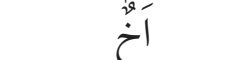 \\
\hline 4 & saudara perempuan & sister & اخجْتُ \\
\hline 5 & kakek & grandfather & جَدُّ \\
\hline 6 & nenek & grandmaother & جَدََّّة \\
\hline 7 & paman & uncle & عَبُّْ \\
\hline 8 & $b i b i$ & aunt & عَمَّة \\
\hline B. & \multicolumn{3}{|c|}{ Benda-Benda dalam Kelas } \\
\hline 1 & buku & book & كرَّاسَة \\
\hline 2 & buku gambar & drawing book & كَتَابُ الرِّنمْ \\
\hline 3 & penggaris & ruller & مسنطرَة \\
\hline 4 & meja & table & مَكَكْتَبَة \\
\hline 5 & kursi & chair & كُرْنيُ \\
\hline 6 & lemari & cupboard & دَوْلاكتُ \\
\hline 7 & pintu & door & بَابُّ \\
\hline 8 & jendela & window & نَافذَة \\
\hline 9 & papan tulis & whiteboard & سَبَوُْورة \\
\hline 10 & tembok & wall & جدار \\
\hline C. & \multicolumn{3}{|c|}{ Profesi } \\
\hline 1 & dokter & doctor & طَبيْتُ \\
\hline 2 & petani & farm & فَلََ ${ }^{2}$ \\
\hline 3 & guru & teacher & مُدَرَسِّ \\
\hline 4 & polisi & police & سُرْطِيّة \\
\hline 5 & pilot & pilot & طَيَّارِّو \\
\hline 6 & perawat & nurse & 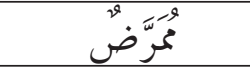 \\
\hline D. & \multicolumn{3}{|c|}{ Binatang } \\
\hline 1 & onta & camel & جَمَالُ \\
\hline 2 & kambing & goat & غَنَمَ \\
\hline 3 & sapi & cow & بَقَّهو \\
\hline 4 & kucing & cat & قطٌ \\
\hline
\end{tabular}




\begin{tabular}{|c|c|c|c|}
\hline 5 & ayam & chicken & دَجَّاجْ \\
\hline 6 & kera & monkey & قرْد \\
\hline 7 & singa & lion & آَسدُ \\
\hline 8 & ikan & fish & سَمَكَ \\
\hline 9 & burung & bird & طَّن \\
\hline 10 & kupu-kupu & butterfly & \\
\hline E. & \multicolumn{3}{|c|}{ Anggota Tubuh } \\
\hline 1 & kepala & head & رَأَسْ \\
\hline 2 & rambut & hair & شَأرَّر \\
\hline 3 & mata & eye & عَيْن \\
\hline 4 & telinga & ear & أَذْن \\
\hline 5 & hidung & noose & أَنْفَ \\
\hline 6 & mulut & mouth & فَمْ مُ \\
\hline 7 & gigi & tooth & سنّ \\
\hline 8 & lidah & tongue & لسَانَ \\
\hline 9 & tangan & hand & يَ يَدُّ \\
\hline 10 & kaki & foot & رجْلٌ \\
\hline F. & \multicolumn{3}{|c|}{ Buah-Buahan } \\
\hline 1 & apel & apple & 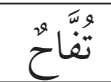 \\
\hline 2 & anggur & grape & عنَبُْ \\
\hline 3 & pisang & banana & مَوْزْ \\
\hline 4 & nanas & pineapple & آنَانَسُ \\
\hline 5 & manggis & mangoes & مَنْجُ" \\
\hline 6 & mangga & mango & مَنْجَاً \\
\hline 7 & jeruk & orange & 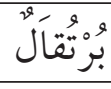 \\
\hline G. & \multicolumn{3}{|c|}{ Alat Transportasi } \\
\hline 1 & pesawat & plane & طاَعَرَّة \\
\hline 2 & kapal laut & ship & سَفِيْنَة \\
\hline 3 & sepeda & cycle & دَرَّاجَةُ \\
\hline 4 & sepeda motor & motor cycle & جَوَّالَة \\
\hline 5 & mobil & car & سَيَّارَة \\
\hline
\end{tabular}




\begin{tabular}{|c|c|c|c|}
\hline 6 & kereta api & train & قطَارٌ \\
\hline H. & \multicolumn{3}{|c|}{ Nama-Nama Hari } \\
\hline 1 & senin & sunday & اثْنَيْنْ \\
\hline 2 & selasa & monday & ثُالَثَاء \\
\hline 3 & rabu & tuesday & رَبَاء \\
\hline 4 & kamis & wetnesday & حَمَيْسُ \\
\hline 5 & jumat & thursday & جَمْعَةُ \\
\hline 6 & sabtu & freeday & سَبْتى \\
\hline 7 & minggu & saturday & اَحَد \\
\hline & Total & 64 & 64 \\
\hline
\end{tabular}

Sumber: Guru Kelas pada TKIT Anak Sholeh Kediri, Lombok Barat

Berdasarkandata pada tabel di atas, dapat lihat bahwa kata benda yang diajarkan pada anak TKIT Anak Sholeh Kediri terdiri atas 8 kelompok dengan total 64 kata. Kedelapan kelompok kata benda tersebut yaitu: kelompok kata benda yang berupa anggota keluarga sejumlah 8 kata. Benda-benda dalam kelas sejumlah 10 kata. Kata benda yang berupa profesi sejumlah 7 kata. Kata benda yang berupa nama-nama binatang sejumlah 10 kata. Kata benda yang berupa nama-nama anggota tubuh sejumlah 10 kata. nama buah-buahan sejumlah 7 kata. Nama-nama alat transportasi sejumlah 6 kata, dan nama-nama hari sejumlah 7 kata.

Dari beberapa klasifikasi kata benda tersebut akan diambil 6 kata-kata baru untuk mengujicoabakan metode drilling. Kata-kata baru yang dimaksud adalah 6 buah kata benda yang berupa alat transportasi. Adapun kata-kata tersebut adalah: pesawat, kapal laut, sepeda, sepeda motor, mobil, dan kereta api.

Kata benda yang berupa alat transportasi diambil sebagai data penelitian karena kata benda jenis ini merupakan kata-kata baru bagi mereke sedangkan jenis kata benda yang lainnya pernah mereka pelajari. Dengan demikian, penentuan jenis kata yang dijadikan sebagai data penelitian ini berkaitan dengan saran bahwa penggunaan metode drilling untuk mengajarkan kata-kata baru.

\section{b. Kata kerja}

Adapun jenis kata kerja yang diajarkan pada anak TKIT Anak Sholeh Kediri tampak pada tabel berikut. 
Tabel 4.

Daftar Kata Kerja yang Diajarkan pada Anak TKIT Anak Sholeh Kediri

\begin{tabular}{|c|c|c|c|}
\hline No & Kata Kerja & Bahasa Inggris & Bahasa Arab \\
\hline 1 & baca & red & قَرَاَ \\
\hline 2 & tulis & write & كَتَبَ \\
\hline 3 & mandi & bath & اسْتَحَمَّم \\
\hline 4 & makan & eat & اكَكَ \\
\hline 5 & minum & drink & شَرَبَ \\
\hline 6 & belajar & learn & دَرَسَ \\
\hline 7 & buka & open & فَتَحَ \\
\hline 8 & tutup & close & قَفَل \\
\hline 9 & pulang & go home & رَجَاً \\
\hline 10 & pergi & go & ذَهَبَ \\
\hline \multicolumn{2}{|r|}{ Total } & 10 & 10 \\
\hline
\end{tabular}

Sumber: Guru Kelas pada TKIT Anak Sholeh Kediri, Lombok Barat

Berdasarkan tabel kata kerja di atas dapat dilihat bahwa kata kerja tidak memiliki klasifikasi sebagaimana kata benda. Jumlah kata kerja yang telah diajarkan pada siswa TKIT Anak Sholeh Kediri adalah sejumlah 5 kata dan yang akan diajarkan sekaligus sebagai data dalam penelitian ini juga berjumlah lima buah kata. Adapun kata-kata baru untuk menguji metode ini adalah: baca, tulis, mandi, makan, dan minum.

c. Kata sifat

Berdasarkan pengklasifikasian kata sifat yang diajarkan di TKIT Anak Sholeh Kediri hanya satu yaitu kelompok kata sifat warna. Kata sifat warna yang diajarkan tersebut tampak pada tabel berikut.

Tabel 5.

Daftar Kata Sifat warna yang Diajarkan pada Anak TKIT Anak Sholeh Kediri

\begin{tabular}{|c|c|c|c|}
\hline No & Kata Sifat & Bahasa Inggris & Bahasa Arab \\
\hline 1 & putih & white & ابَيَضَ \\
\hline 2 & merah & red & اَحَمَرَ \\
\hline 3 & hitam & black & اسَسوَدُ \\
\hline 4 & biru & blue & أَرْرَق \\
\hline 5 & kuning & yellow & اَسْفَوُو \\
\hline 6 & hijau & green & اَخْضرَ \\
\hline
\end{tabular}




\begin{tabular}{|c|c|c|c|}
\hline 7 & coklat & brown & اَسَسْمَرُ \\
\hline 8 & ungu & purple & ارَجُوَنَي \\
\hline \multicolumn{2}{|c|}{ Total } & 8 & 8 \\
\hline
\end{tabular}

Sumber: Guru Kelas pada TKIT Anak Sholeh Kediri, Lombok Barat

Berdasarkan tabel tersebut dapat dilihat bahwa dari beberapa klasifikasi kata sifat yang telah disebutkan di atas, hanya satu klasifikasi kata sifat yang diajarkan pada siswa TKIT Anak Sholeh Kediri yaitu kata sifat yang berupa warna. Adapun jumlah kata sifat yang diajarkan adalah 4 kata yaitu merah, putih, hitam dan biru sedangkan kata-kata sifat yang lain tersebut telah dipelajari.

\section{d. Kata bilangan}

Bentuk-bentuk numeralia yang diajarkan ini tampak pada tabel berikut.

Tabel 6.

Daftar Kata Bilangan yang Diajarkan pada Anak TKIT Anak Sholeh Kediri

\begin{tabular}{|c|c|c|c|}
\hline No & Kata Bilangan & Bahasa Inggris & Bahasa Arab \\
\hline A. & \multicolumn{3}{|c|}{ Kata Bilangan Pokok } \\
\hline 1 & satu & one & وَحَحُ \\
\hline 2 & dua & two & أَثْنَانَ \\
\hline 3 & tiga & tree & 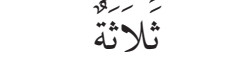 \\
\hline 4 & empat & four & أَرْبِعَةُ \\
\hline 5 & lima & five & خَمْسْةُة \\
\hline 6 & enam & six & ستَّة \\
\hline 7 & tujuh & seven & سَبْعَةُة \\
\hline 8 & delapan & eight & ثَتَانَيَة \\
\hline 9 & sembilan & nine & تسْعَة \\
\hline 10 & sepuluh & ten & عَشَرَة \\
\hline B. & \multicolumn{3}{|c|}{ Kata Bilangan Gugus } \\
\hline 1 & sebelas & eleven & اَحَدَ عَشَرَ \\
\hline 2 & dua belas & twelve & اثَْْنَ عَشَ \\
\hline 3 & tiga belas & thirten & ثَالثَة عَشَر \\
\hline 4 & empat belas & four ten & اَرْبِعَةَ عَشَرَ \\
\hline 5 & lima belas & five ten & خَمَْسةَ عَشَرَ \\
\hline 6 & enam belas & six ten & ستَّةَ عَشَرَ \\
\hline 7 & tujuh belas & seven ten & سَبْعَةَ عَشَرَ \\
\hline
\end{tabular}




\begin{tabular}{|c|c|c|c|}
\hline 8 & delapan belas & eight ten & ثَََانَيَةَ عَشَرَ \\
\hline 9 & sembilan belas & nine ten & تسنعَةَ عَشَرَ \\
\hline 10 & dua puluh & twenty & عشُروْْن \\
\hline & Total & 20 & 20 \\
\hline
\end{tabular}

Sumber: Guru Kelas pada TKIT Anak Sholeh Kediri, Lombok Barat

\section{Penerapan metode drilling di Kelas}

Pembelajaran kosakata kata baru tersebut dilakukan selama sepuluh hari atau dua minggu. Setiap hari terdapat dua kata baru yang diajarkan dengan menggunakan metode drilling. Teknis penerapan metode drillingdilakukan dalam tiga tahapan yang dirincikan dalam uraian berikut.

a. Pendahuluan

Pada bagian pendahuluan ini, peneliti melakukan penjadwalan terhadap pengajaran kosakata baru tersebut. Dalam hal ini, peneliti menentukan kata yang diajarkan setiap hari. Sebagaimana yang disebutkan sebelumnya bahwa setiap hari ada dua kata baru yang diajarkan. Pembelajaran dilakukan selama 30 menit sebelum jam pelajaran berakhir. Jadwal ini berfungsi sebagai acuan untuk mengorganisasi kegiatan pembelajaran sehingga guru mengetahui kata-kata yang sudah dan yang belum diajarkan. Adapun jadwal pengajaran kosakata tersebut tampak pada tabel berikut.

Tabel 10.

Jadwal Pembelajaran Kosakata Baru pada Anak TKIT Anak Sholeh Kediri

\begin{tabular}{|c|c|c|}
\hline No & Hari/Tgl & Kosakata yang Diajarkan \\
\hline 1 & Senin, 4 November 2013 & pesawat, kapal laut \\
\hline 2 & Selasa, 5 November 2013 & sepeda motor, sepeda \\
\hline 3 & Rabu, 6 November 2013 & mobil, kereta api \\
\hline 4 & Kamis, 7 November 2013 & baca, tulis \\
\hline 5 & Jumat, 8 November 2013 & mandi, makan \\
\hline 6 & Senin, 11 November 2013 & minum, buang \\
\hline 7 & Selasa, 12 November 2013 & merah, putih \\
\hline 8 & Rabu, 13 November 2013 & hitam, biru, \\
\hline 9 & Kamis, 14 November 2013 & sebelas, dua belas, \\
\hline 10 & Jumat, 15 November 2013 & tiga belas, empat belas \\
\hline
\end{tabular}




\section{b. Pelaksanaan Pengajaran dengan Metode Drilling}

Setelah dilakukan penjadwalan sebagaimana tertera pada tabel di atas, tahapan berikutnya adalah penerapan metode drilling. Penerapan metode drilling ini dilakukan dengan beberapa tahapan, yang pertamaadalah presentasi. Presentasi dalam pengertian ini adalah guru menyebutkan kosakata baru di hadapan siswa sedangkan siswa menyimak kosakata yang disebutkan guru tersebut. Presentasi ini dilakukansebanyak 3 kali dengan metode klasikal. Misalnya ketika pengajaran kata bendapesawat dan kapal laut, guru menyebutkan kedua kata tersebut masing-masing sebanyak 3 kali. Kata pesawat dan kapal laut disebutkan berikut terjemahan bahasa Inggris dan bahasa Arabnya. Bentuk presentasi yang dilakukan guru yaitu menyebutkan kata pesawat langsung diikuti bahasa Inggrisnya sebanyak $3 \mathrm{kali}$, begitu juga dengan presentasi bahasa Arabnya.

Tahapan kedua, adalah pemodelan. Pemodelan dalam hal ini berarti bahwa guru menyebutkan kosakata yang diajarkan berikut arti kata tersebut dalam bahasa Inggris dan bahasa Arab. Sebagaimana pada tahap presentasi, tahap pemodelan ini juga dilakukan sebanyak 3 kali dengan metode klasikal. Setiap kali guru menyebutkan kosakata yang diajarkan, siswa diminta untuk mengikuti apa yang diucapkan guru. Inilah yang disebut dengan pemodelan, yaitu meniru suatu kegiatan berdasarkan suatu sumber yaitu model. Dalam pembelajaran kosakata bahasa asing ini, pemodelan berarti bahwa kata yang diujarkan oleh guru beserta artinya dalam bahasa Inggris dan Arab diikuti secara persis oleh siswa. Pemodelan ini dilakukan sebanyak 3 kali. Misalnya guru mengucapkan pesawat(blan) 3 kali. kapal laut (ship) 3 kali. Kata yang di dalam kurung merupakan kata bahasa Inggris begitu juga pada saat pengajaran bahasa Arab. Secara langsung siswa akan mengikuti kata-kata tersebut. Demikianlah pemodelan ini dilakukan dengan maksud siswa mengikuti apa yang diucapkan guru.

Tahapan ketigaadalah penggunaan. Guru memberikan penegasan kepada siswa untuk menggunakan kata-kata baru yang diajarkan dalam percakapan seharihari. Penggunaan dalam hal ini berarti bahwa ketika melakukan percakapan, siswa diharuskan menggunakan kata-kata baru tersebut untuk menguatkan ingatan mereka. Tahapan penggunaan ini dilakukan dengan metode individual. Penggunaan kata-kata ini tidak diharuskan dengan struktur bahasa yang tepat secara kaidah. Artinya, dalam penggunaan kata-kata tersebut terkadang harus diinterferensikan dengan kosakta bahasa lain. Misalnya, seorang siswa ingin mengatakan bahwa dia ingin naik pesawat, maka kalimat yang diujarkan berbunyi saya ingin naik blane atau saya ingin naik طَاعِرَّة. Begitu juga dengan beberapa kosakata lainnya.

Tahapan selanjutnya yaitu tahapan keempat, yaitu siswa diajak untuk mengartikan atau mendefiniskan setiap kata baru yang diajarkan. Misalnya kata pesawat diartikan dalam bahasa Inggris dan Arab kemudian diberikan penjelasan 
atau pemaknaan tentang pesawat tersebut. Tahapan pendefinisian ini dilakukan dengan metode klasikal. Adapun bentuk pemaknaan ini adalahguru mengaitkan sesuatu yang berhubungan dengan benda yang dirujuk oleh kata yang diajarkan. Hal ini dilakukan dengan maksud agar siswa betul-betul mengetahui banyak hal yang berkaitan dengan kata tersebut sehingga ingatan mereka terhadap kata-kata baru yang diajarkan melekat kuat.

Tahapan kelima adalah mengulang. Setelah setiap tahapan di atas dilaksanakan, diadakan pengulangan atau review terhadap kata-kata baru yang diajarkan. Kegiatan ini dilakukan dengan cara siswa melakukan demonstrasi yaitu menyebutkan kosakata yang diajarkan beserta bahasa Inggris dan Arabnya. Setelah pengulangan ini dilakukan, guru melakukan pengujian ingatan. Dalam hal ini guru akan menunjuk beberapa siswa untuk menyebutkan bahasa Inggrisdan bahasa Arab kata-kata baru yang diajarkan. Demikianlah beberapa tahapan dalam penerapan metode drilling. Adapun tingkat penguasaan siswa TKIT Anak Sholeh Kediri dalam pembelajaran kosakata bahasa Asing yaitu bahasa Inggris dan Arab dijelaskan pada subbab di bawah ini.

c. Persentase Tingkat Penguasaan Kosakata Bahasa Asing pada Siswa TK dengan Menggunakan Metode Drilling

Telah dijelaskan beberapa tahapan dalam pengajaran kosakata bahasa asing (Inggris dan Arab) dengan penerapan metode drilling pada siswa TKIT Anak Sholeh Kediri. Pada subbab 4.3.4 ini akan diuraikan deskripsi atau gambaran penguasaan kosakata bahasa asing pada siswa TKIT Anak Sholeh Kediri. Untuk mengetahui tingkat penguasaan siswa, diadakan tes setiap akhir pelajaran dan satu kali tes untuk pemahaman seluruh kosakata yang diajarkan. Persentase penguasaan kosakata bahasa asing dengan penerapan metode drillingdapat dilihat pada tabel di bawah ini.

Tabel 11. Persentase Penguasaan Kata Benda Bahasa Asing pada Siswa TKIT Anak Sholeh Kediri

\begin{tabular}{|c|c|c|c|}
\hline Kosakata & $\begin{array}{c}\text { Persentase } \\
\text { Bhs Inggris }\end{array}$ & $\begin{array}{c}\text { Persentase } \\
\text { Bhs Arab }\end{array}$ & Persentase masing-masing kata \\
\hline Pesawat & $83 \%$ & $78 \%$ & $80 \%$ \\
\hline kapal laut & $78 \%$ & $65 \%$ & $71,5 \%$ \\
\hline $\begin{array}{c}\text { sepeda mo- } \\
\text { tor }\end{array}$ & $96 \%$ & $96 \%$ & $96 \%$ \\
\hline Sepeda & $100 \%$ & $87 \%$ & $93,5 \%$ \\
\hline mobil & $100 \%$ & $87 \%$ & $93,5 \%$ \\
\hline kereta api & $83 \%$ & $87 \%$ & $85 \%$ \\
\hline \multicolumn{2}{|c|}{ Persentase penguasaan kata benda } & $87 \%$ \\
\hline
\end{tabular}


Berdasarkan tabel di atas, dapat dilihat tingkat penguasaan bahasa asing siswa TKIT Anak Sholeh Kediri pada beberapa kata benda. Penguasaan tersebut dapat dirincikan yaitu: persentase penguasaan kata pesawat mencapai angka $80 \%$. Sedangkan persentase penguasaan kata kapal laut mencapai 71,5\%. Kata sepeda motor mencapai angka 96\%, sedangkan kata sepeda mencapai angka 93,5\%. Adapun kata mobil persentase penguasaan siswa adalah 93,5\% dan kata kereta api mencapai angka $85 \%$. Berdasarkan perincian ini dapat disimpulkan bahwa rata-rata persentase penguasaan siswa TKIT Anak Sholeh pada kata benda yang diajarkan adalah $87 \%$.

Tabel 12. Persentase Penguasaan Kata Kerja Bahasa Asing pada Siswa TKIT Anak Sholeh Kediri

\begin{tabular}{|c|c|c|c|}
\hline Kosakata & $\begin{array}{c}\text { Persentase Bhs } \\
\text { Inggris }\end{array}$ & $\begin{array}{c}\text { Persentase Bhs } \\
\text { Arab }\end{array}$ & Persentase masing-masing kata \\
\hline baca & $83 \%$ & $87 \%$ & $85 \%$ \\
\hline tulis & $100 \%$ & $83 \%$ & $91,5 \%$ \\
\hline mandi & $96 \%$ & $96 \%$ & $96 \%$ \\
\hline makan & $91 \%$ & $91 \%$ & $91 \%$ \\
\hline minum & $78 \%$ & $96 \%$ & $87 \%$ \\
\hline buang & $83 \%$ & $69 \%$ & $76 \%$ \\
\hline \multicolumn{2}{|c|}{ Persentase penguasaan kata benda } & $88 \%$ \\
\hline
\end{tabular}

Berdasarkan tabel di atas, dapat dilihat tingkat penguasaan kata kerja bahasa asing pada siswa TKIT Anak Sholeh Kediri. Penguasaan tersebut dapat dirincikan yaitu: persentase penguasaan kata baca mencapai angka $85 \%$. Sedangkan persentase penguasaan katatulis mencapai 91,5\%. Kata mandi mencapai angka 96\%, sedangkan kata makanmencapai angka 91\%. Adapun kata minum persentase penguasaan siswa adalah $87 \%$ dan kata buang mencapai angka $76 \%$. Berdasarkan perincian ini dapat disimpulkan bahwa rata-rata persentase penguasaan siswa TKIT Anak Sholeh pada kata kerja yang diajarkan adalah $88 \%$.

Tabel 13.

Persentase Penguasaan Kata Sifat Bahasa Asing pada Siswa TKIT Anak Sholeh Kediri

\begin{tabular}{|c|c|c|c|}
\hline Kosakata & $\begin{array}{c}\text { Persentase } \\
\text { Bhs Inggris }\end{array}$ & $\begin{array}{c}\text { Persentase } \\
\text { Bhs Arab }\end{array}$ & Persentase masing-masing kata \\
\hline merah & $87 \%$ & $87 \%$ & $87 \%$ \\
\hline putih & $83 \%$ & $83 \%$ & $83 \%$ \\
\hline hitam & $96 \%$ & $65 \%$ & $80,5 \%$ \\
\hline biru & $83 \%$ & $83 \%$ & $83 \%$ \\
\hline \multicolumn{2}{|c|}{ Persentase penguasaan kata benda } & $83 \%$ \\
\hline
\end{tabular}


Berdasarkan tabel di atas, dapat dilihat tingkat penguasaan kata sifat bahasa asing pada siswa TKIT Anak Sholeh Kediri. Penguasaan tersebut dapat dirincikan yaitu: persentase penguasaan kata merah mencapai angka $87 \%$. Sedangkan persentase penguasaan kataputih mencapai $83 \%$. Kata hitam mencapai angka 80,5\%, sedangkan kata biru mencapai angka $83 \%$. Berdasarkan perincian ini dapat disimpulkan bahwa rata-rata persentase penguasaan siswa TKIT Anak Sholeh pada kata sifat yang diajarkan adalah $83 \%$.

Tabel 14.

Persentase Penguasaan Kata Bilangan Bahasa Asing pada Siswa TKIT Anak Sholeh Kediri

\begin{tabular}{|c|c|c|c|}
\hline Kosakata & $\begin{array}{c}\text { Persentase } \\
\text { Bhs Inggris }\end{array}$ & $\begin{array}{c}\text { Persentase } \\
\text { Bhs Arab }\end{array}$ & Persentase masing-masing kata \\
\hline Sebelas & $87 \%$ & $65 \%$ & $76 \%$ \\
\hline dua belas & $87 \%$ & $91 \%$ & $89 \%$ \\
\hline tiga belas & $65 \%$ & $78 \%$ & $71,5 \%$ \\
\hline empat belas & $52 \%$ & $56,5 \%$ & $54 \%$ \\
\hline \multicolumn{2}{|c|}{ Persentase penguasaan kata benda } & $73 \%$ \\
\hline
\end{tabular}

Berdasarkan tabel di atas, dapat dilihat tingkat penguasaan kata bilangan bahasa asing pada siswa TKIT Anak Sholeh Kediri. Penguasaan tersebut dapat dirincikan yaitu: persentase penguasaan kata sebelas mencapai angka $76 \%$. Sedangkan persentase penguasaan katadua belas mencapai $89 \%$. Kata tiga belas mencapai angka $71,5 \%$, sedangkan kata empat belasmencapai angka 54\%. Berdasarkan perincian ini dapat disimpulkan bahwa rata-rata persentase penguasaan siswa TKIT Anak Sholeh pada kata bilangan yang diajarkan adalah $73 \%$.

Berdasarkan data-data tabel di atas, dapat rincikan persentase penguasaan beberapa kelas kata bahasa asing pada siswa TKIT Anak Sholeh Kediri. Persentase penguasaan kata benda mencapai angka $87 \%$, kata kerja mencapai angka $88 \%$, sedangkan kata sifat mencapai angka $83 \%$, dan kata bilangan mencapai angka $73 \%$. Berdasarkan perincian ini dapat disimpulkan bahwa persentase penguasaan kosakata bahasa asing pada siswa TKIT Anak Sholeh Kediri yang paling dominan adalah kata kerja dengan tingkat penguasaan sebanyak $88 \%$. Dengan demikian jika dirataratakan, pembelajaran bahasa asing dengan metode drilling pada siswa TKIT Anak Sholeh Kediri mencapai angka 83\%. Dari hasil persentase ini dapat disimpulkan bahwa pembelajaran bahasa asing dengan metode drillingpada anak TKIT Anak Sholeh dapat dikatakan efektif.

Persentase penguasaan kosakata bahasa asing ini merupakan perincian dari hasil tes I dan II terhadap pembelajaran bahasa asing dengan metode drillingpada siswa TKIT Anak Sholeh Kediri. 


\section{E. SIMPULAN}

1. Beberapa bentuk kelas kata bahasa asing yang diajarkan pada anak TKyaitu:

a. kelas kata benda yang terdiri atas nama-nama anggota keluarga, bendabenda dalam kelas, profesi, binatang, anggota tubuh, buah-buahan, alatalat transportasi, dan nama-nama hari,

b. kelas kata kerja,

c. kelas kata sifat yang terdiri atas nama-nama warna, dan

d. kelas kata bilangan yang terdiri atas kata bilangan pokok dan bilangan gugus.

2. Deskripsi penerapan metode drilling di kelas dalam pembelajaran kosakata bahasa asing pada anak TK

3. Penerapan metode drilling dilakukan dengan beberapa tahapan yaitu: pertama,peneliti melakukan penjadwalan terhadap pengajaran kosakata bahasa asing. Kedua tahapan berikutnya dalam penerapan metode drilling adalah presentasi. Tahapan ketiga, pemodelan dan tahapan keempat penggunaan. Tahapan selanjutnya yaitu tahapan kelimadilakukan dengan cara siswa diajak untuk mengartikan atau mendefiniskan setiap kata baru yang diajarkan. Tahapan keenamberupa pengulangan dan tahapan terakhir yaitu melakukan pengujian untuk menilai tingkat ketercapaian belajar dengan metode drilling. 


\section{DAFTAR PUSTAKA}

Alwasilah, A. C.. 1993. Sosiologi Bahasa. Bandung: Angkasa.

Aprilia. H.B.. 2010. 'Pemerolehan Kosakata Bahasa Indonesia Anak Usia 1 - 3 Tahun; Studi Kasus di PAUD Anak Sholeh Kelurahan Turide, Kecamatan Sandubaya'. Skripsi Universitas Mataram, Mataram.

Arifin, Z.. dan Matanggui, H.J. 2007. Morfologi: Bentuk, Makna, dan Fungsi. Jakarta: Grasindo.

Chaer, A.. 2003. Linguistik Umum. Jakarta: Penerbit Rineka Cipta. . 2003. Seputar Tata Bahasa Baku Bahasa Indonesia. Jakarta: Penerbit Rineka Cipta

Dardjowidjojo, S.. 2010. Psikolinguistik: Pengantar Pemahaman Bahasa Manusia. Jakarta: Yayasan Obor Indonesia.

Djajasudarma, F. 2006. Metode Linguistik: Ancangan Metode Penelitian dan Kajian. Bandung: Reflika Aditama.

Halimatussakdiah. 2008. 'Meningkatkan Kemampuan Siswa dalam Menyusun Sinopsis dengan Menggunakan Metode Drill pada Pelajaran Bahasa Indonesia di Kelas 6 SDN 3 Montong Baan’ PTK Lombok Timur.

Keraf, G.. 1991. Tata Bahasa Rujukan Bahasa Indonesia: untuk Tingkat Pendidikan Menengah. Jakarta: PT. Grasindo.

1996. Pembentukan Kata dalam Bahasa Indonesia. Jakarta: PT. Gramedia.

Mahsun, 2011. Metode Penelitian Bahasa Tahapan strategi, metode, dan tekniknya. Jakarta: PT Raja Grafindo Persada.

Mar’at, S.. 2011. Psikolinguistik: Suatu Pengantar. Bandung: Reflika Aditama.

Muslich, M.. 2010. Garis-Garis Besar TataBahasa Baku Bahasa Indonesia. Bandung: Refika Aditama.

Ramlan, M. 2001. Morfologi: Suatu Tinjauan Deskriptif. Yogyakarta: C.V. Karyono.

Verhaar, J.W.M. 1996. Asas-Asas Linguistik Umum. Yogyakarta: Gajah Mada University Press. 